

\title{
THE DETERMINANTS OF SYSTEMATIC RISK: A FIRM LIFECYCLE
}

\section{PERSPECTIVE}

\author{
Jimmy A. Saravia ${ }^{\dagger}$ \\ Carlos S. Garcia* \\ Paula M. Almonacid ${ }^{\dagger}$
}

December $12^{\text {th }}, 2016$

\begin{abstract}
This paper investigates how of systematic risk varies over the lifecycle of the firm. If market equity beta is determined by firm characteristics as the literature on the determinants of systematic risk holds, and if those characteristics change over the lifecycle of the firm following a definite pattern as firm lifecycle theory suggests, then market equity beta should change over the lifecycle of the firm following a predictable pattern. Our findings indicate that, holding other determinants of beta constant, the coefficient of systematic risk tends to fall in magnitude following a nonlinear pattern as firm age increases. In addition, we find that the volatility of market equity beta also tends to fall over the lifecycle of the firm. We argue that our main variable of concern, i.e. firm age, proxies for variables that have hitherto been omitted in the literature on the determinants of systematic risk. In particular, we maintain that firm age may proxy for the positive reputation that firms acquire over time with shareholders. This research is useful for both practitioners and researchers in that it may suggest ways to adjust empirical estimates of systematic risk. In addition, our results are important for research on beta forecasting as they show that the length of the stationary interval of betas is shorter for young companies, so that beta forecasting may be less accurate for firms in the early stages of their lifecycle compared to beta forecasting for mature firms.
\end{abstract}

KEYWORDS: Systematic risk, firm lifecycle, intrinsic business risk, financial leverage, operating risk.

JEL CLASSIFICATION: G11, G12

\footnotetext{
$\dagger$ Professors, Grupo de Investigación en Banca y Finanzas, School of Economics and Finance, Center for Research in Economics and Finance (CIEF), Universidad EAFIT, Carrera 49 Número 7 Sur 50, Medellín, Colombia, e-mails: palmona1@eafit.edu.co and jsaravia@eafit.edu.co

${ }^{*}$ Research assistant, Grupo de Investigación en Banca y Finanzas, School of Economics and Finance, Center for Research in Economics and Finance (CIEF), Universidad EAFIT, Carrera 49 Número 7 Sur 50, Medellín, Colombia, email: cgarci73@eafit.edu.co
} 
Quite apart from this regression tendency, it is reasonable to suppose that betas do change over time in systematic ways in response to certain changes in the structure of companies (Blume 1975, p. 785, n. 1).

\section{INTRODUCTION}

The study of the determinants of systematic risk (market equity beta) is of great importance for the disciplines of corporate finance and accounting (Hong and Sarkar, 2007; Mandelker and Rhee, 1984; Schlueter and Siever, 2014). Moreover, market equity betas are extensively used by practitioners for a variety of purposes (Graham and Harvey, 2001; Groenewold and Fraser, 2000). The relevant literature has so far identified several important real determinants of systematic risk, such as the effects of financial and operating risk on beta (Gahlon and Gentry, 1982; Hamada, 1972; Hill and Stone, 1980; Mandelker and Rhee, 1984), the impact of intrinsic business risk on beta (Chung, 1989; Griffin and Dugan, 2003; Mensah, 1992; Schlueter and Sievers, 2014) and the impact of default and growth options on systematic risk (Hong and Sarkar, 2007). On the other hand, although the literature finds that systematic risk seems to be satisfactorily explained by accounting measures of these determinants, it has not ruled out the potential influence of omitted variables on the results (Hill and Stone, 1980; Mandelker and Rhee, 1984; Mensah, 1992).

In this paper we extend the literature on the determinants of systematic risk by examining how beta varies over the lifecycle of the firm. According to firm lifecycle theory the structure of companies changes following predictable pattern as organizations mature. Accordingly, if betas are a function of firm characteristics such as asset structure, capital structure, and other

attributes of real assets as the literature on the determinants of market equity beta suggests, then it is reasonable to presume that betas should also vary following a particular pattern over 
the lifecycle of the firm. On the other hand, the inclusion of firm lifecycle variables, such as firm age, could mitigate the potential impact of omitted variables on econometric results as these variables can proxy for factors that vary over the lifecycle of the firm but are difficult to measure quantitatively. Examples of such factors have been enumerated in the literature. For instance, Mensah (1992, p. 187) points out that "the firm's competitive strategy, its position within an industry, the barriers to entry to the industry, and the bargaining power of the firm relative to its customers and suppliers all affect a firm's systematic risk" but are "either not observable directly, or difficult to measure quantitatively." To this list other factors could be added, in particular the positive reputation that firms may acquire over time with their current and potential shareholders as we discuss in the theoretical section of this paper.

Following this line of reasoning, we investigate empirically how betas vary over the lifecycle of the firm by running regressions equations that, in addition to the traditional determinants of systematic risk, include firm age as proxy for potential omitted variables that may change over time following a distinct pattern. We find that as predicted by theory market equity beta tends to fall in magnitude as firms mature and that it does so following a nonlinear pattern. In addition, we investigate the variability of market equity beta over the lifecycle of the firm and find evidence that the volatility of beta also falls as firms become older.

The study of the determinants of market equity beta and the behavior of beta over time is important because of its multiple applications both in academic research and in practice. For instance, corporate managers, investors and other practitioners often use market equity beta estimates when making investment decisions in order to compute the cost of capital for 
a particular project, or in valuation models when deciding whether or not to acquire another firm. Conversely, academic researchers often use market equity beta estimates in event studies to measure cumulative abnormal returns, as well as in investigations aiming to test asset pricing models. In each of these cases research on the determinants of beta and on the behavior of beta over time may prove useful to adjust empirical estimates of systematic risk. ${ }^{1}$ Since our results suggest that the determinants of beta uncovered in the literature change following a predictable pattern over the lifecycle of the firm, the study of the behavior of systematic risk over the lifecycle of the firm may also help both academics and practitioners make better adjustments to their estimates of market equity beta and achieve enhanced results in their particular activities. To the best of our knowledge, up to this point no prior study in the literature on the determinants of beta has systematically investigated the behavior of market equity betas over the lifecycle of the firm. To make this contribution is one of the main objectives of this work.

The remainder of this paper is organized as follows. Section 2 examines the determinants of systematic risk from the perspective of the lifecycle theory of the firm and deduces testable propositions. Section 3 presents our econometric models. Section 4 describes the sample and presents the paper's results. Section 5 concludes.

\footnotetext{
${ }^{1}$ In a well-known paper Blume (1975) finds that betas show a tendency to revert towards the average beta of 1.0 over time. This finding has suggested techniques to adjust estimates of market equity beta used in practice. For instance, Bloomberg provides betas which are calculated as a weighted average of the regression estimate of beta and 1.0.
} 


\section{THE DETERMINANTS OF SYSTEMATIC RISK OVER THE LIFECYCLE OF THE FIRM}

According to firm lifecycle theory the financial and other economic characteristics of companies change over time following a distinct pattern. This was already recognized in the

first half of last century by eminent economists such as Schumpeter (1934, 1943), who suggested that firms usually start as innovative entrepreneurial companies and end up as bureaucratic managerial corporations.

Mueller $(1969,1972,2003$, pp. 81-83) has argued in his firm lifecycle theory that young firms have much better opportunities to grow and expand than mature firms. Firms generally start their lifecycle with financial characteristics such as negative free cash flows (FCF) and a constant need for outside sources of funding in order to finance rapid and volatile growth. Because of their strained finances, their undiversified business, and the higher uncertainty resulting from rapid growth, firm lifecycle theory suggests that the vulnerability of young companies to economy wide shocks is also higher than that of mature companies so that their market equity betas should be relatively higher. Moreover, likelihood of bankruptcy is higher for young companies so that many firms do not make it to the mature stage. In contrast, Mueller's firm lifecycle theory maintains that the growth opportunities of mature firms are inferior compared to those of young firms. Mature firms are characterized by having positive FCF which allows them to payout of a percentage of their earnings as dividends to shareholders. Mature firms are depicted as more stable, more diversified and consequently with lower risk and uncertainty associated to them. This is reflected in characteristics such as lower volatility of cash flows from operations and sales. Consequently, firm lifecycle 
theory suggests that mature companies are more robust to systematic shocks compared to young firms so that their betas should be comparatively lower.

The upshot is that because of the abovementioned predictable changes in the structure companies over time, an empirical test designed to study the behavior of beta should find that beta falls over the lifecycle of the firm. So far several papers have provided some evidence supporting firm lifecycle theory's claims regarding the different characteristics of young firms compared to mature firms (Garcia, Saravia and Yepes, 2016; Mueller and Yun, 1998; Saravia, 2014; Saravia and Saravia-Matus, 2016). However, to the best of our knowledge no paper has yet tested empirically whether the market equity betas of young firms are larger than those of mature firms while holding other real determinants of systematic risk constant.

It is likely that difficult to measure factors such as the bargaining power of the firm visà-vis customers and suppliers, its position within the industry, its competitive strategy, etc. which have been pointed out by Mensah (1992) as potential omitted factors in the literature on the determinants of systematic risk may also change following a particular pattern over the lifecycle of the firm. In our opinion, however, there are other more important factors which will likely change over the lifecycle of the firm and play a key role in the determination of a company's coefficient of systematic risk. In particular, the positive reputation that firms may acquire over time with shareholders plays a very important role in the determinant of systematic risk but up to now it has not been taken into account. If this reasoning is valid, the inclusion of empirical measures of firm age should proxy for these variables. In the empirical sections below we will test this prediction by including the age of the firm as an additional explanatory variable in addition to the traditional determinants of systematic risk. 
In addition to changes in company structure, an important factor to take into consideration is how investors learn about the financial and economic prospects of companies over their lifecycles and how they learn about those of the market as a whole. From a Bayesian theory of knowledge ${ }^{2}$ perspective we can imagine investors in every time period transforming their prior probabilities concerning the expected returns and the risk of a particular company by using new evidence about the company and the market acquired during that period to generate posterior probabilities concerning the expected returns and the risk of the firm (Figure 1). ${ }^{3}$

\section{[Insert Figure 1 here]}

At the early stages of the lifecycle of a firm the level of confidence that investors can be expected to place on their prior probabilities regarding the expected return and the risk of the company are likely to be lower than for the case of mature firms. This is because investors are basing their probabilities on less experience and data since the history of the young firm is shorter. Consequently, we can expect that when investors transform their prior probabilities about the expected returns and the risk of a young firm by using new evidence acquired during the current time period to generate their posterior probabilities, the resulting posterior probabilities will tend to vary considerably from the prior probabilities especially if an economic shock occurs during that period of time. On the other hand, we can expect investors will place a heavier weight on their prior probabilities regarding the expected returns of mature firms, so that when the prior probabilities are transformed by acquiring new evidence to generate their posterior probabilities, the resulting posterior probabilities should not

\footnotetext{
${ }^{2}$ See Talbott (2015).

${ }^{3}$ A similar learning process would also take place to form the probabilities regarding the expected returns and the risk of the market as a whole.
} 
deviate too much from the prior probabilities even if an economic shock occurs during that time period. Therefore, we can expect that the market equity betas of young firms should display more volatility in their values than those of mature firms. We will also test this additional proposition in the empirical section of this paper.

\section{MODEL SPECIFICATION}

To test the first prediction of the paper, that market equity beta will tend to fall in magnitude over the lifecycle of the firm, we estimate the following equation:

$$
\begin{aligned}
\beta_{i t}=\alpha_{0} & +\alpha_{1} \text { firmage }_{i t}+\alpha_{2} \text { growth }_{i t}+\alpha_{3} \text { bu }_{\text {sin } \text { essrisk }_{i t}}+\alpha_{4} \text { financiall everage }_{i t} \\
& +\alpha_{5} \text { operatingrisk }_{i t}+\alpha_{6} \text { firmsize }_{i t}+\alpha_{7} \text { growthoptions }_{i t}+\sum_{t=1}^{T-1} \theta_{t} \text { Time }_{i t}+\varepsilon_{1 i t}
\end{aligned}
$$

Where $\beta_{i t}$ is market equity beta for firm $i$ at time $t$, and is estimated using the market model where both the returns of the firm and those of the market include capital gains and dividend yields. Since previous work by Groenewold and Fraser (2009) and Kim (1993) suggests that five years is a reasonable time period to estimate systematic risk we calculate beta using monthly return data over the last 60 months for each firm at each point in time. ${ }^{4}$

The first independent variable, firmage $e_{i t}$, is the age of firm $i$ at time $t$ measured in years since its incorporation. Our theoretical discussion predicts that systematic risk will fall over the lifecycle of the firm. However it does not inform us about the functional form of this relationship, hence in the empirical section we will experiment with several functional forms of the firmage variable. The outcome of the test of this hypothesis is one of the main concerns

\footnotetext{
${ }^{4}$ See the appendix for the sources of data and a description of how the variables are constructed.
} 
of this paper. The second independent variable, growth $h_{i t}$, is proxied by the percentage change in the sales of firm $i$ from year $t-1$ to year $t$. Gahlon and Gentry's (1982) decomposition of beta model suggests that an increase in revenue will reduce systematic risk, for this reason we expect that systematic risk should be negatively related to growth. Next, businessrisk $_{i t}$, is intended to measure the intrinsic business risk of firm $i$ at time $t$. We measure this variable as the standard deviation of the percentage changes in yearly net sales over the 5 years prior to $t$. According to the literature on the determinants of beta we should expect that systematic risk will tend to increase with intrinsic business risk, and vice-versa, therefore the coefficient of this variable should have a positive sign (Chung, 1989; Schlueter and Sievers, 2014).

The fourth explanatory variable financialleverage $i t$ is the financial leverage of firm $i$ at time $t$ and it is measured as the book value of debt divided by the market value of equity plus the book value of debt. The literature on the impact of financial leverage on beta starting with Hamada's (1972) paper has shown that there exists a positive relationship between these two variables, for this reason we expect that the coefficient of the financial leverage variable will show a positive sign. The next regressor, operatingrisk $k_{i t}$, is the operating risk of firm $i$ at time $t$. We proxy this variable using the standard deviation of the percentage change in yearly firm funds from operations over the 5 years preceding time $t$. Operating risk increases the volatility of funds from operations, and an increase in the latter should lead to larger market equity betas. In line with the extant literature, we expect that the coefficient of operatingrisk ${ }_{i t}$ will have a positive sign (Chung, 1989; Schlueter and Sievers, 2014).

As a sixth determinant of systematic risk we include the size of the firm, firmsize $e_{i t}$, which is measured as the natural logarithm of total assets (in constant 2010 USD) for firm $i$ at time $t$. Since a larger firm may likely have a lower probability of default (Hasan, Hossain and 
Cheung, 2015), larger firms should have lower systematic risk and vice-versa. For this reason, we expect to find a negative coefficient of the firm size variable. Finally, we include the independent variable growthoptions $i t$ to account for the growth options of firm $i$ at time $t$. Hong and Sarkar (2007) have shown that market equity beta is an increasing function of growth options, hence we expect a positive coefficient for this variable. Since the Q-theory of investment states that investment opportunities should increase with Tobin's q (Jovanovic and Russeau, 2002), we proxy the growth options of the firm using a measure of Tobin's q.

Lastly, we include time dummy variables to control for the impact of contemporaneous macroeconomic conditions which affect all firms but change over time and, in addition, we will use a firm fixed effects model specification to control for the time invariant characteristics of firm $i$ which are not picked up by the independent variables. As discussed in the empirical section, the decision to use a fixed effects model specification is based on the implementation of a test by Schaffer and Stillman (2010) to choose between fixed and random effect models which can be extended to heteroskedastic and cluster-robust versions.

In addition to estimating equation (1), we will also test the theoretical prediction that the market equity betas of young firms should display more volatility than those of mature firms. To do this we will estimate the following equation:

$$
\begin{aligned}
\text { betavolatility }_{i t}= & \gamma_{0}+\gamma_{1} \text { firmage }_{i t}+\gamma_{2} \text { growt }_{i t}+\gamma_{3} \text { bu } \sin \text { essrisk }_{i t}+\gamma_{4} \text { financiall everage }_{i t} \\
& +\gamma_{5} \text { operatingrisk }_{i t}+\gamma_{6} \text { firmsize }_{i t}+\gamma_{7} \text { growthoptions }_{i t}+\sum_{t=1}^{T-1} \lambda_{t} \text { Time }_{i t}+\varepsilon_{2 i t}
\end{aligned}
$$

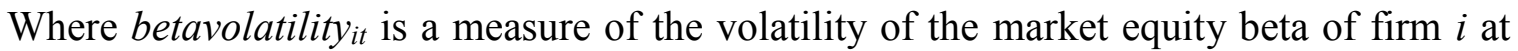
time $t$, and all the independent variables are defined the same as before. We will use two measures of beta volatility. The first measure is the standard deviation of the percentage 
changes in yearly market equity betas of over the last 5 years, and the second is the mean absolute deviation (MAD) of the percentage changes in yearly market equity betas over the previous 5 years. Our theoretical discussion in section 2 predicts that the volatility of systematic risk will fall over the lifecycle of the firm (a negative sign for the coefficient of firmage). However it does not inform us about the functional form of this relationship, therefore we will experiment with different functional forms for the firmage variable.

We expect that the volatility of market equity beta will increase with growth and growthoptions (coefficients with positive signs for these two variables). Due to the higher uncertainty that new projects represent, investors will likely place less weight on their prior probabilities regarding the expected returns and the risk of fast growing firms with better growth options, so that when investors transform their prior probabilities by using new evidence to generate their posterior probabilities, the resulting posterior probabilities will likely tend to vary considerably from prior probabilities, as discussed in section 2 . In addition, we expect that the volatility of systematic risk will also increase with intrinsic business risk, financial leverage and operating risk (positive coefficients for these variables). Given the higher uncertainty on how highly levered firms with high intrinsic business risk may perform, investors will likely have less confidence on their prior probabilities concerning the expected returns and risk of these firms, so that in this case posterior probabilities will also likely vary substantially from prior probabilities for similar reasons as discussed above. In contrast, we expect that the volatility of market equity beta will fall with firmsize (a negative sign for the coefficient of firmsize). This is because large companies are usually more economically and financially stable. Moreover, there is usually more information available about larger companies since more financial analysts are likely to follow them. Hence, investors will 
likely place higher weight on their prior probabilities regarding the expected returns and the risk of large firms, so that when investors transform their prior probabilities by using new evidence to generate posterior probabilities, these posterior probabilities will likely not vary too much from prior probabilities.

Finally, we include time dummy variables to control for the impact of contemporaneous macroeconomic conditions which affect all firms but change over time and, additionally, will employ a fixed firm effects specification to capture the characteristics of firm $i$ which do not change over time and are not picked up by the explanatory variables. As discussed below, this choice of model specification is based on our implementation of the test by Schaffer and Stillman (2010) to choose between fixed and random effect models, which unlike the classic Hausman test, can be extended to heteroskedastic and cluster-robust versions.

\section{DATA AND ECONOMETRIC RESULTS}

\subsection{Sample selection and description}

We start the screening process with all U.S. firms available in the Datastream database. Since we estimate market equity betas using 60 months of returns, we require that firms are 5 or more years old and that firm return data for the previous 60 months is available. Since Datastream allows us to compute betas starting in 1988 at the earliest, our period of study starts in that year and comprises the time period from 1988 to 2014. In addition, we require that firms have real total assets of USD 50 million or more (in constant 2010 USD) and have no missing values in all the variables included in equation (1) for at least one year during the period 1988-2014 to be included in the sample. We also exclude banks, insurance and 
financial services companies. At the end of this process we are left with an unbalanced panel dataset comprising 2,346 different companies over a time period of 27 years.

Table 1 presents summary statistics for the variables of interest described in section 3 . We winsorize observations in the outside $1 \%$ of each tail of the growth, businessrisk, financialleverage, operatingrisk, and growthoptions variables to mitigate the effect of extreme values in the regressions.

\section{[Insert Table 1 here]}

Pairwise correlations are presented in Table 2. As can be seen, the age of the firm (firmage) has a negative correlation with beta $(\beta)$ which is significant at the $1 \%$ level. This is a preliminary corroboration that systematic risk tends to fall as firms mature as indicated by firm lifecycle theory. In contrast, however, the table shows that the correlation between firm age and the volatility of market equity beta (betavolatility) is slightly positive but insignificant at the 5\% level. This preliminary result does not corroborate the relevant prediction in our theoretical section.

\section{[Insert Table 2 here]}

As mentioned in the theoretical section, firm lifecycle theory suggests that the structures of companies change over time following a predictable pattern. This proposition seems to be corroborated by several of the correlations presented in Table 2. In particular, the correlations between firm age and growth on the one hand, and firm age and growthoptions on the other, are negative and significant at the $1 \%$ level, which suggests that young firms grow faster and have better growth opportunities than mature firms as put forward by lifecycle theory. Moreover, the correlation between firm age and firmsize is positive and significant, which 
indicates that firms tend to become larger as they mature. Interestingly, the correlations between firm age and our measures of intrinsic business risk (businessrisk) and operating risk (operatingrisk) are both negative and significant at the $1 \%$ level, which suggests that the magnitude of these two sources of systematic risk tends to fall as firms mature. In contrast, it is interesting to note that the correlation between firm age and financial leverage (financialleverage) is positive and significant at the $1 \%$ level. Which suggests that financial leverage increases over the lifecycle of the firm.

On the other hand, the correlations between beta and businessrisk, beta and operatingrisk, beta and growthoptions and beta and financialleverage are positive and statistically significant (the first three correlations are significant at the $1 \%$ level and the last one at the $5 \%$ level). These preliminary results are consistent with the findings of the literature on the determinants of systematic risk (Chung, 1989; Hong and Sarkar, 2007; Mensah, 1992; Schlueter and Sievers, 2014).

Finally, Table 2 shows that the correlations between betavolatility and growth, betavolatility and businessrisk, betavolatility and operatingrisk and betavolatility and financialleverage are positive and significant (the first three correlations are significant at the $5 \%$ level and the last one at the 1\% level), as expected from our discussion in section 3 . However, the correlation between the volatility of beta and growthoptions is negative and significant at the $1 \%$ level which does not conform to our predictions as stated in section 3 . Conversely, the correlation between betavolatility and firmsize is negative and significant at the $1 \%$ level as expected. 


\subsection{Results part 1: Systematic risk over the lifecycle of the firm}

Table 3 presents our main results concerning the relationship between systematic risk, firm age and other determinants of market equity beta (equation 1). To choose between a fixed and a random effect model specification we implemented the test proposed by Schaffer and Stillman (2010) which has the advantage of being valid in the presence of heteroscedasticity or clustered errors. Since the results of this test rejected the adequacy of the random effects specification at any conventional level of significance, the equations in Table 3 were estimated using fixed effects (test not reported).

\section{[Insert Table 3 here]}

As discussed previously firm lifecycle theory predicts that systematic risk will fall over the lifecycle of the firm, nevertheless it does not inform us about the functional form of this relationship. One sensible description of the relationship between market equity beta and firm age is presented in Figure 2. In that figure, young companies have a beta which is greater than the average beta of 1.0 since according to firm lifecycle theory young firms are typically riskier than mature firms, on the other hand mature firms should have a smaller beta than the average of 1.0 for the same reason. Finally, the figure shows that systematic risk may rise again towards the average of 1.0 or greater during the declining phase of the firm's lifecycle.

\section{[Insert Figure 2 here]}

Following this reasoning, we implement a quadratic functional form for firm age in column 1a of Table 3. As shown in the table the coefficient of firmage is negative and 
significant at the $5 \%$ level while the coefficient of firmage 2 is positive and significant at the $1 \%$ level. This suggests that, consistent with firm lifecycle theory, beta falls initially as the firm matures but then it rises again as the firm enters its declining phase.

To further investigate the relationship between systematic risk and firm age, we employ two additional functional forms. First, column $1 \mathrm{~b}$ of Table 3 implements a reciprocal functional form for firm age. As can be seen, the coefficient of $1 /$ firmage is positive and significant at the $1 \%$ level. This particular result suggests that the fall in the magnitude of systematic is quite pronounced over the early stages of a firm's development, but that it stabilizes as firm's mature so that it reaches a horizontal asymptote as firm age increases indefinitely. In addition, column 1c of Table 3 uses a logarithmic transformation of firm age. As shown, the coefficient of the natural logarithm of firm age, $\ln$ (firmage), is negative and significant at the $1 \%$ level. This result also suggests that there is a pronounced fall in the value of systematic risk at the early stages of the lifecycle of the firm, but that the rate of decline in the magnitude of market equity beta diminishes for mature firms.

Of the three functional forms, we believe that the quadratic specification makes the most sense as it allows for the possibility that market equity beta may rise again during the declining phase of the lifecycle of the firm (Figure 2). In contrast, the logarithmic transformation probably makes the least sense as it does not rule out the possibility that beta becomes negative as firm age increases indefinitely. The reciprocal functional form is interesting as it suggests that beta falls substantially during the first years of the lifecycle of the firm, however, it rules out the possibility that systematic risk increases for declining firms at the later stages of firm lifecycle. Lastly, we note that in terms of fit to the data we cannot 
choose the best among the three estimated equations as all of them present a very similar adjusted $\mathrm{R}^{2}$.

Turning to the traditional determinants of market equity beta studied in the financial and accounting literature we find that, for the three regression equations reported in Table 3 , the coefficients of businessrisk, financialleverage and operatingrisk are all positive as expected, and that the coefficients of the first two variables are significant at the $1 \%$ level while the coefficient of the last variable is significant at the $5 \%$ level. Thus our results provide evidence in support of the proposition that higher levels of financial leverage, operating risk and intrinsic business risk lead to higher systematic risk. In addition, we find that as expected the coefficient of growhtoptions is positive and significant at the $1 \%$ level, suggesting that firms with higher growth options have higher systematic risk. On the other hand, the results show that the coefficient of the growth variable is negative as expected but it is statistically insignificant. Finally, the coefficient of firmsize is negative as expected but it is only significant at the $5 \%$ in column $1 \mathrm{~b}$. Overall, these results are consistent with the extant literature on the determinants of systematic risk, but in addition, they show that betas change following a particular pattern over the lifecycle of the firm as evidenced by the findings related to the firm age coefficients.

One issue with these results is that the procedure uses overlapping observations to calculate the five-year market equity betas (i.e. a beta estimated at time $t$ shares $80 \%$ of the data used to estimate beta at time $t-1$ ) which causes serial correlation in the error term, so that OLS standard errors are unreliable. To remedy this we have used standard errors clustered by firm that allow for autocorrelation and heteroskedasticity. Comparing the latter with OLS standard errors we find that the standard errors clustered by firm we have used are twice or 
thrice as large depending on the regressor. This suggests that there is serial correlation in the error term. Therefore, we implement an alternative method to check our results as follows. In Table 4, we rerun the regressions using only the data for the years 1994, 1999, 2004, 2009 and 2014 so that we only employ betas estimated using non-overlapping observations.

\section{[Insert Table 4 here]}

Once again, to choose between a fixed and a random effects model specification we implemented the test proposed by Schaffer and Stillman (2010). Since this test also rejected the adequacy of the random effects specification at any conventional level of significance, we re-estimated equation (1) using fixed effects (test not reported). The results, presented in Table 4, show that several of the key results do not change qualitatively if we use nonoverlapping observations. Importantly, the coefficients of firm age in columns 1a', 1b' and $1 c^{\prime}$ all have the expected signs and are significant at the $1 \%$ level. In addition, businessrisk and financialleverage also show the expected positive sign and remain significant at the $1 \%$ level. On the other hand, the coefficient of growth stays negative as expected and now becomes significant at the $1 \%$ level. Another noteworthy difference is that while the coefficients of operating risk, firm size and growth options maintain their expected signs they all become statistically insignificant. In another vein, note that in table 4 we also use standard errors clustered by firm. Comparing the latter with OLS standard errors we find that the standard errors clustered by firm are now only slightly larger. This is an indication that, for these equations estimated using non-overlapping betas, there is no serial correlation in the error term. Overall, we conclude that the evidence strongly suggest that in addition to the traditional determinants of systematic risk, firm lifecycle explanatory variables have an important role to play in a theory of the determinants of market equity beta. 


\subsection{Results part 2: The volatility of systematic risk over the lifecycle of the firm}

Table 5 presents our main results regarding the relationship between the volatility of market equity beta, firm age and other determinants (equation 2). In this table we employ two measures of beta volatility: the standard deviation and the mean absolute deviation of the yearly percentage changes in market equity beta, both over the 5 years preceding time $t$. Because of the five years of data needed to construct these variables the time period under study is now 22 years, from 1993 to 2014. Once more, we start by conducting the test proposed by Schaffer and Stillman (2010) to decide the between the use of fixed or random effects. Again we find that the test rejects the adequacy of the random effects specification at any conventional level of significance (test not reported). Hence we report results estimated using fixed effects.

Firm lifecycle theory suggests that the volatility of systematic risk should fall as firms mature. However, it does not specify the functional relationship between the volatility of market equity beta and firm age. Hence, in column $2 \mathrm{a}$ we regressed beta volatility on firm age, firm age squared and other real determinants of systematic risk to investigate whether the relationship between these two variables is quadratic. As can be seen, we found that the coefficient of firmage is negative and significant at the $1 \%$ level, while on the other hand we

found that the coefficient of firmage $e^{2}$ is positive but insignificant at any conventional level, which suggests that the relationship between the volatility of systematic risk and firm age is linear. Thus, in column $2 \mathrm{~b}$ we re-estimate equation (2) using a linear specification for firm age. As shown in column $2 \mathrm{~b}$ of Table 5, we find that the coefficient of the variable firmage is negative as expected and significant at the $1 \%$ level. 
As a robustness check, in column $2 \mathrm{c}$ we re-estimate equation (2) but on this occasion we winsorize observations in the outside $1 \%$ of each tail of betavolatility (also measured as the standard deviation of the yearly percentage changes in market equity beta over the 5 years preceding time $t$ ) to mitigate the effect of extreme values in the regression. As can be seen, the results indicate that although the magnitude of the coefficient of firmage falls, it is still negative as expected and significant at the $1 \%$ level.

As a further robustness check, in Table 5 column $2 \mathrm{~d}$ we re-estimate equation (2) using the mean absolute deviation (MAD) of the yearly percentage changes in market equity beta over the 5 years preceding time $t$ as the dependent variable. As shown, we find that the coefficient of firmage is negative as expected and significant at the $1 \%$ level. Thus our results in Table 5 suggest that the volatility of beta falls over the lifecycle of the firm as discussed in section 2 .

Turning to the other independent variables, we find that the coefficient of growth is positive as expected and significant at the $1 \%$ or $5 \%$ level depending on the regression. This suggests that beta is more volatile for fast growth firms. Additionally, we find that the coefficient of firmsize is negative as expected and significant at the $1 \%$ level, which suggests that the volatility of systematic risk is lower for larger firms. On the other hand, the table shows that the coefficients of other explanatory variables in equation (2) are insignificant at any conventional level.

As in the previous section, in Table 5 we have used standard errors clustered by firm that allow for autocorrelation and heteroskedasticity. Comparing these errors with OLS standard errors we find that the standard errors clustered by firm we have used are twice or thrice as 
large depending on the explanatory variable. This suggests that there is serial correlation in the error term. Therefore, as a final check, in unreported results we re-run the regressions reported in Table 5 using only data for the years 1994, 1999, 2004, 2009 and 2014. We find similar results to those presented in Table 5. Particularly, the coefficient of firmage is still negative as expected and significant at the 5\% level or better. Moreover, the coefficient of firmsize is also negative as expected and significant at the $1 \%$ level. The main difference is that the coefficient for growth although still positive becomes insignificant at any conventional level. The coefficients of other explanatory variables remain statistically insignificant. Comparing standard errors clustered by firm with OLS standard errors we find that this time the standard errors clustered by firm are now only marginally larger. This is an indication that, for these equations estimated using data for the years 1994, 1999, 2004, 2009 and 2014 , there is no serial correlation in the error term. On the whole, we conclude that the evidence strongly suggest that the volatility of beta falls as firms mature and that the volatility of beta is lower for larger firms.

\section{CONCLUSION}

Firm lifecycle theory predicts that the characteristics of companies will change over time following foreseeable pattern. On the other hand, the literature on the determinants of market equity betas has indicated that the latter are a function of firm characteristics such as asset structure, capital structure, and other attributes of real assets. Taking these two premises into account this paper has argued that that betas should also change following a distinct pattern

over the lifecycle of the firm. The correlation matrix presented in Table 2 provides some 
evidence in favor of this prediction as it shows that both systematic risk and its determinants tend to change in a distinct way as firms mature.

Some writers in the literature on the determinants of systematic risk have pointed out as a potential limitation of their work the influence of omitted variables on their results, and lists of such variables have been published. We have argued that this problem can be mitigated by using firm lifecycle variables, in particular the age of the firm, as a proxy for variables that vary over the lifecycle of the firm but are difficult to measure quantitatively. Importantly, we have suggested that a crucial factor which will likely change over the lifecycle of the firm and play a key role in the determination of a company's coefficient of systematic risk is the positive reputation that firms acquire over time. After all, practitioners often like to point out that reputation is their greatest asset. The econometric results presented in Tables 3 to 5 provide some evidence supporting our arguments. The results suggest that beta falls rapidly in the early stages of the lifecycle of the firm, then it stabilizes as firms mature and then increases again in the declining stages of the firm (see Figure 2). On the other hand, as mentioned in the empirical section, implementation of the test proposed by Schaffer and Stillman (2010) to decide the between the use of fixed or random effects indicated that we should use fixed effects to estimate our regression equations. This suggests that time invariant firm characteristics, which are not picked up by the observable variables, are also relevant for the determination of market equity beta. However, these firm characteristics have not been generally taken into account, as the literature on the determinants of systematic risk has mainly relied on cross-sectional specifications or it has not used fixed effects. Nevertheless, we find that even after including firm lifecycle variables and using fixed effects our results are consistent with the conclusions in literature on the 
determinants of systematic risk, as they show that beta tends to increase with factors such as operating risk, financial leverage, business risk and growth options (Tables 3 and 4).

Finally, in addition to the results concerning the magnitude of market equity beta over the lifecycle of the firm, this paper has investigated how the volatility of beta changes as firms mature. In this regard, the results in Table 5 show that the volatility of beta falls as firms get older, and also that the volatility of beta is lower for larger firms. Taken together the results in this paper are important for the literatures that study the non-stationarity of beta and beta forecasting (e.g. Groenewold and Fraser, 2009; and Kim, 1993), since they suggest that the magnitude and volatility of systematic risk changes substantially from period to period in the early stages of the lifecycle of the firm and that the changes become less pronounced over time. The implication is that the length of the stationary interval of betas is probably shorter for young companies compared to mature firms, so that beta forecasting may be less accurate for firms in the early stages of their lifecycle.

\section{APPENDIX}

This appendix describes the construction of the empirical variables utilized in this paper and the sources of data used to build them. Our main source of market and accounting data is Datastream.

To compute market equity beta we use the following Datastream formula: REGB\#(LN\#(X(LI\#RI)/LAG\#(X(LI\#RI),1M)),LN\#(X(RI)/LAG\#(X(RI),1M)),60M) which returns the beta coefficient from a market model regression in which the market index is the S\&P 500 Composite. We include the RI datatype (total return) in the formula so that both the 
returns of the firm and the returns of the market include capital gains and dividend yields. On the other hand, we construct variable betavolatility at the end of year $t$ by calculating the yearly percentage changes in market equity beta over the previous 5 years and then computing the standard deviation of those changes.

We calculate the firm age variable at the end of year $t$, by subtracting the date of

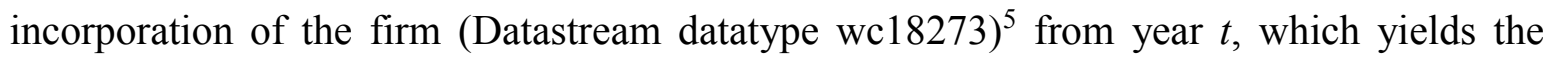
number of years since the firm's incorporation. The variable growth is measured at the end of year $t$ by computing the percentage change in the firm's net sales (wc01001) between the end of year $t-1$ and the end of year $t$.

We construct the businessrisk variable at the end of year $t$ by computing yearly percentage changes in net sales (wc01001) over the previous 5 years and then calculating the standard deviation of those changes. The variable financialleverage is computed by dividing the book value of total debt (wc03255) by the firm's market capitalization (wc08001) plus the book value of total debt. The variable operatingrisk at the end of year $t$ is constructed by calculating the yearly percentage changes in the firm's funds from operations (wc04201) over the preceding 5 years and then calculating the standard deviation of those changes. The variable firmsize is constructed by taking the book value of total assets (wc02999), adjusting them for inflation and then taking the natural logarithm of this value (thus, we use the natural logarithm of total assets in thousands of constant 2010 U.S. dollars as a measure of firm size).

The variable growthoptions is proxied using Tobin's $q$. Tobin's $q$ is computed by dividing the market value of the firm over the book value of total assets (wc02999). Where,

\footnotetext{
${ }^{5}$ In this appendix Datastream datatypes are presented in parenthesis.
} 
the market value of the firm is calculated by adding the firm's market capitalization (wc08001) to its total debt (wc03255) and preferred stock (wc03451). We winsorize observations in the outside $1 \%$ of each tail of the growth, businessrisk, financialleverage, operatingrisk, and growthoptions variables to mitigate the effect of extreme values in the regressions. The CPI data for the United States were taken from the International Monetary Fund, World Economic Outlook Database, of April 2015.

\section{REFERENCES}

Blume, M. E. 1975. Betas and Their Regression Tendencies. The Journal of Finance 30: 785795.

Chung, K. H. 1989. The Impact of the Demand Volatility and Leverages on the Systematic Risk of Common Stocks. Journal of Business Finance and Accounting 16: 343-360.

Gahlon, J. M. and Gentry, J. A. 1982. On the Relationship between Systematic Risk and the Degree of Operating and Financial Leverage. Financial Management 11: 15-23.

Garcia, C., Saravia, J. A. and Yepes, D. 2016. The Weighted Average Cost of Capital over the Lifecycle of the Firm. The Corporate Board: Role, Duties \& Composition 12: 96103.

Graham, J. R. and Harvey, C. R. 2001. The Theory and Practice of Corporate Finance: Evidence from the Field. Journal of Financial Economics 60, 187-243. 
Griffin, H. F. and Dugan, M. T. 2003. Systematic Risk and Revenue Volatility. The Journal of Financial Research 26: 179-189.

Groenewold, N. and Fraser, P. 2000. Forecasting Beta: How Well Does the 'Five-Year Rule of Thumb' Do? Journal of Business Finance \& Accounting 27: 953-982.

Hamada, R. S. 1972. The Effect of the Firm's Capital Structure on the Systematic Risk of Common Stocks. The Journal of Finance 27: 435-452.

Hasan, M., Hossain, M. and Cheung, A. 2015. Corporate life cycle and cost of equity capital. Journal of Contemporary Accounting \& Economics 11: 46-60.

Hill, N. C. and Stone, B. K. 1980. Accounting Betas, Systematic Operating Risk, and Financial Leverage: A Risk-Composition Approach to the Determinants of Systematic Risk. Journal of Financial and Quantitative Analysis 15: 595-637.

Hong, G. and Sarkar, S. 2007. Equity Systematic Risk (Beta) and Its Determinants. Contemporary Accounting Research 24: 423-466.

Jovanovic, B., and P. L. Rousseau. 2002. The Q-Theory of Mergers. The American Economic Review 92: 198-204.

Kim, D. 1993. The Extent of Nonstationarity of Beta. Review of Quantitative Finance and Accounting 3: 241-254.

Mandelker, G. N. and Rhee, S. G. 1984. The Impact of the Degrees of Operating and Financial Leverage on Systematic Risk of Common Stock. Journal of Financial and Quantitative Analysis 19: 45-57. 
Mensah, Y. M. 1992. Adjusted Accounting Beta, Operating Leverage and Financial Leverage as Determinants of Market Beta: A Synthesis and Empirical Evaluation. Review of Quantitative Finance and Accounting 2: 187-203.

Mueller, D. C. 1969. A Theory of Conglomerate Mergers. Quarterly Journal of Economics 83: 643-659.

Mueller, D.C. 1972. A Life Cycle Theory of the Firm. The Journal of Industrial Economics 20: 199-219.

Mueller, D. C. 2003. The Corporation: Investments, Mergers and Growth. London: Routledge.

Mueller, D. C., and S. L. Yun. 1998. Rates of Return over the Firm's Lifecycle. Industrial and Corporate Change 7: 347-368.

Saravia, J. A. 2014. The Lifecycle of the Firm, Corporate Governance and Investment Performance. Corporate Ownership and Control 11: 212-226.

Saravia, J. A., and Saravia-Matus, S. (2016). Corporate Governance and Transaction Cost Economics: A Study of the Equity Governance Structure. The Corporate Board: Role, Duties \& Composition, 12: 33-44.

Schaffer, M.E., Stillman, S. 2010. xtoverid: Stata module to calculate tests of overidentifying restrictions after xtreg, xtivreg, xtivreg2 and xthtaylor URL = http://ideas.repec.org/c/boc/bocode/s456779.html 
Schlueter, T. and Sievers, S. 2014. Determinants of Market Beta: The Impacts of FirmSpecific Accounting Figures and Market Conditions. Review of Quantitative Finance and Accounting 42: 535-570.

Schumpeter, J. A. 1934. The Theory of Economic Development. London: Transaction Books.

Schumpeter, J. A. 1943. Capitalism, Socialism and Democracy. London: George Allen \& Unwin Ltd.

Talbott, W. 2015. Bayesian Epistemology. The Stanford Encyclopedia of Philosophy. URL = http://plato.stanford.edu/archives/sum2015/entries/epistemology-bayesian/ 


\section{Table 1. Summary statistics}

Notes: $\beta$ is market equity beta estimated using monthly return data (capital gains plus dividend yields) over the previous 5 years, see appendix. betavolatility is the standard deviation of the yearly percentage changes in market equity beta over the previous 5 years. firmage is the age of the firm measured in years since its incorporation date. growth is measured as the percentage change in the firm's net sales between the end of year $t-1$ and the end of year $t$. businessrisk is proxied by the standard deviation of the yearly percentage changes in the net sales of the firm over the previous 5 years. financialleverage is measured by dividing the book value of total debt by the market value of equity plus the book value of total debt. operatingrisk is proxied by the standard deviation of the yearly percentage changes in the firm's funds from operations over the preceding 5 years. firmsize is measured as the natural logarithm of the book value of total assets in thousands of constant 2010 U.S. dollars. growthoptions is proxied using Tobin's q, which is measured as the market value of the firm at the end of year $t$ divided by the book value of total assets at the end of year $t$. We winsorize observations in the outside $1 \%$ of each tail of the growth, businessrisk, financialleverage, operatingrisk, and growthoptions variables to mitigate the effect of extreme values in the regressions.

\begin{tabular}{lrrrrrr}
\hline Variable & $\mathrm{N}$ & Mean & Median & Std. Dev. & Min & Max \\
\hline$\beta$ & 29317 & 1.17 & 1.08 & 0.69 & -2.68 & 6.22 \\
betavolatility & 18662 & 0.48 & 0.22 & 1.49 & 0.01 & 78.64 \\
firmage & 29317 & 36.73 & 26.00 & 28.74 & 5.00 & 195.00 \\
growth & 29317 & 0.10 & 0.07 & 0.26 & -0.53 & 1.39 \\
businessrisk & 29317 & 0.24 & 0.14 & 0.40 & 0.02 & 3.19 \\
financialleverage & 29317 & 0.22 & 0.16 & 0.21 & 0.00 & 0.87 \\
operatingrisk & 29317 & 1.41 & 0.36 & 3.64 & 0.05 & 27.47 \\
firmsize & 29317 & 13.92 & 13.78 & 1.79 & 10.82 & 20.58 \\
growthoptions & 29317 & 1.60 & 1.21 & 1.22 & 0.32 & 7.36 \\
\hline
\end{tabular}




\section{Table 2. Correlation matrix}

See Table 1 for variable definitions. We winsorize observations in the outside $1 \%$ of each tail of the growth, businessrisk, financialleverage, operatingrisk, and growthoptions variables to mitigate the effect of extreme values in the regressions. $* *$ and $*$ designate that a correlation is statistically significant at the $1 \%$ and $5 \%$ level respectively.

\begin{tabular}{|c|c|c|c|c|c|c|c|c|c|}
\hline Variable & firmage & $\beta$ & $\begin{array}{c}\text { beta- } \\
\text { volatility }\end{array}$ & growth & $\begin{array}{l}\text { business- } \\
\text { risk }\end{array}$ & $\begin{array}{c}\text { financial- } \\
\text { leverage }\end{array}$ & $\begin{array}{c}\text { operating- } \\
\text { risk }\end{array}$ & firmsize & $\begin{array}{l}\text { growth- } \\
\text { options }\end{array}$ \\
\hline firmage & 1.00 & & & & & & & & \\
\hline$\beta$ & $-0.18^{* *}$ & 1.00 & & & & & & & \\
\hline betavolatility & 0.01 & $-0.09 * *$ & 1.00 & & & & & & \\
\hline growth & $-0.10 * *$ & 0.01 & $1.02 *$ & 1.00 & & & & & \\
\hline businessrisk & $-0.15 * *$ & $0.14 * *$ & $0.02 *$ & $0.25^{* *}$ & 1.00 & & & & \\
\hline financialleverage & $0.03 * *$ & $0.01 *$ & $0.05 * *$ & $-0.08 * *$ & $0.02 * *$ & 1.00 & & & \\
\hline operatingrisk & $-0.10 * *$ & $0.12 * *$ & $0.02 *$ & $0.04 * *$ & $0.16^{* *}$ & 0.01 & 1.00 & & \\
\hline firmsize & $0.23 * *$ & $-0.06^{* *}$ & $-0.12^{* *}$ & -0.01 & $-0.16^{* *}$ & $0.18^{* *}$ & $-0.18^{* *}$ & 1.00 & \\
\hline growthoptions & $-0.11 * *$ & $0.03 * *$ & $-0.03 * *$ & $0.19^{* *}$ & $0.08 * *$ & $-0.45^{* *}$ & $-0.02 * *$ & $-0.07 * *$ & 1.00 \\
\hline
\end{tabular}




\section{Table 3. Regression results for equation (1)}

This table presents the results of regressing market equity beta on firm age and other determinants of systematic risk using fixed effects during the period from 1988 to 2014 (equation 1). Table 1 presents de definitions of the variables included in this table, the construction of the variables is discussed in the appendix. We winsorize observations in the outside $1 \%$ of each tail of the growth, businessrisk, financialleverage, operatingrisk, and growthoptions variables to mitigate the effect of extreme values in the regressions. Note that we include time dummy variables to control for the impact of contemporaneous macroeconomic conditions which affect all firms but change over time. ${ }^{* *}$ and $*$ indicate a statistically significant coefficient at the $1 \%$ and $5 \%$ level respectively. We report standard errors clustered by firm in parentheses.

\begin{tabular}{|c|c|c|c|c|}
\hline Variable & Predicted sign & $1 \mathrm{a}$ & $1 \mathrm{~b}$ & $1 \mathrm{c}$ \\
\hline Intercept & + & $\begin{array}{l}1.5402 * * \\
(0.2226)\end{array}$ & $\begin{array}{c}1.4174 * * \\
(0.2332)\end{array}$ & $\begin{array}{c}2.0543^{* *} \\
(0.2560)\end{array}$ \\
\hline firmage & - & $\begin{array}{l}-0.0069 * \\
(0.0030)\end{array}$ & & \\
\hline firmage $e^{2}$ & + & $\begin{array}{c}0.0001^{* *} \\
(0.0000)\end{array}$ & & \\
\hline 1/firmage & + & & $\begin{array}{l}1.3312^{* *} \\
(0.4379)\end{array}$ & \\
\hline $\ln$ (firmage) & - & & & $\begin{array}{l}-0.2071 * * \\
(0.0506)\end{array}$ \\
\hline growth & - & $\begin{array}{l}-0.0213 \\
(0.0155)\end{array}$ & $\begin{array}{l}-0.0175 \\
(0.0155)\end{array}$ & $\begin{array}{l}-0.0199 \\
(0.0155)\end{array}$ \\
\hline businessrisk & + & $\begin{array}{l}0.1092 * * \\
(0.0292)\end{array}$ & $\begin{array}{l}0.1105^{* *} \\
(0.0294)\end{array}$ & $\begin{array}{c}0.1077 * * \\
(0.0293)\end{array}$ \\
\hline financialleverage & + & $\begin{array}{c}0.2942 * * \\
(0.0610)\end{array}$ & $\begin{array}{l}0.3044 * * \\
(0.0608)\end{array}$ & $\begin{array}{c}0.3014 * * \\
(0.0609)\end{array}$ \\
\hline operatingrisk & + & $\begin{array}{c}0.0053 * \\
(0.0024)\end{array}$ & $\begin{array}{c}0.0056^{*} \\
(0.0024)\end{array}$ & $\begin{array}{c}0.0054 * \\
(0.0024)\end{array}$ \\
\hline firmsize & - & $\begin{array}{l}-0.0278 \\
(0.0171)\end{array}$ & $\begin{array}{l}-0.0339 * \\
(0.0169)\end{array}$ & $\begin{array}{l}-0.0302 \\
(0.0170)\end{array}$ \\
\hline growthoptions & + & $\begin{array}{c}0.0265^{* *} \\
(0.0084)\end{array}$ & $\begin{array}{l}0.0276^{* *} \\
(0.0084)\end{array}$ & $\begin{array}{c}0.0273 * * \\
(0.0084)\end{array}$ \\
\hline $\begin{array}{l}\text { Time dummy } \\
\text { variables? }\end{array}$ & & yes & yes & yes \\
\hline Adjusted $\mathrm{R}^{2}$ & & 0.5327 & 0.5316 & 0.5324 \\
\hline $\begin{array}{l}\text { Number of } \\
\text { observations }\end{array}$ & & 29317 & 29317 & 29317 \\
\hline
\end{tabular}


Table 4. Regression results for equation (1): Beta estimated over non-overlapping 60 month periods

This table presents the results of regressing market equity beta on firm age and other determinants of systematic risk using fixed effects (equation 1). The results in this table are obtained employing data for the years 1994, 1999, 2004, 2009 and 2014 so that the five-year market equity betas are estimated from non-overlapping observations. Table 1 presents de definitions of the variables included in this table, the construction of the variables is discussed in the appendix. We winsorize observations in the outside $1 \%$ of each tail of the growth, businessrisk, financialleverage, operatingrisk, and growthoptions variables to mitigate the effect of extreme values in the regressions. We include time dummy variables to control for the impact of contemporaneous macroeconomic conditions which affect all firms but change over time. ${ }^{* *}$ and $*$ indicate a statistically significant coefficient at the $1 \%$ and $5 \%$ level respectively. We report standard errors clustered by firm in parentheses.

\begin{tabular}{|c|c|c|c|c|}
\hline Variable & Predicted sign & 1a' & $1 b^{\prime}$ & $1 c^{\prime}$ \\
\hline Intercept & + & $\begin{array}{l}1.3539 * * \\
(0.2381)\end{array}$ & $\begin{array}{l}1.0953^{* *} \\
(0.2798)\end{array}$ & $\begin{array}{c}2.3606 * * \\
(0.3187)\end{array}$ \\
\hline firmage & - & $\begin{array}{l}-0.0152 * * \\
(0.0029)\end{array}$ & & \\
\hline firmage $^{2}$ & + & $\begin{array}{l}0.0001^{* *} \\
(0.0000)\end{array}$ & & \\
\hline 1/firmage & + & & $\begin{array}{l}2.5817^{* *} \\
(0.5894)\end{array}$ & \\
\hline $\ln$ (firmage) & - & & & $\begin{array}{l}-0.3499 * * \\
(0.0587)\end{array}$ \\
\hline growth & - & $\begin{array}{l}-0.1546^{* *} \\
(0.0474)\end{array}$ & $\begin{array}{l}-0.1487^{* *} \\
(0.0480)\end{array}$ & $\begin{array}{l}-0.1540 * * \\
(0.0477)\end{array}$ \\
\hline businessrisk & + & $\begin{array}{l}0.1157^{* *} \\
(0.0451)\end{array}$ & $\begin{array}{l}0.1186^{* *} \\
(0.0455)\end{array}$ & $\begin{array}{c}0.1151^{* *} \\
(0.0452)\end{array}$ \\
\hline financialleverage & + & $\begin{array}{l}0.5956^{* *} \\
(0.0882)\end{array}$ & $\begin{array}{l}0.6031^{* *} \\
(0.0884)\end{array}$ & $\begin{array}{l}0.6008^{* *} \\
(0.0884)\end{array}$ \\
\hline operatingrisk & + & $\begin{array}{c}0.0035 \\
(0.0034)\end{array}$ & $\begin{array}{c}0.0039 \\
(0.0034)\end{array}$ & $\begin{array}{c}0.0038 \\
(0.0034)\end{array}$ \\
\hline firmsize & - & $\begin{array}{l}-0.0013 \\
(0.0194)\end{array}$ & $\begin{array}{l}-0.0087 \\
(0.0194)\end{array}$ & $\begin{array}{l}-0.0036 \\
(0.0194)\end{array}$ \\
\hline growthoptions & + & $\begin{array}{c}0.0131 \\
(0.0115)\end{array}$ & $\begin{array}{c}0.0163 \\
(0.0116)\end{array}$ & $\begin{array}{c}0.0151 \\
(0.0115)\end{array}$ \\
\hline $\begin{array}{l}\text { Time dummy } \\
\text { variables? }\end{array}$ & & yes & yes & yes \\
\hline Adjusted $\mathrm{R}^{2}$ & & 0.4226 & 0.4193 & 0.4219 \\
\hline $\begin{array}{l}\text { Number of } \\
\text { observations }\end{array}$ & & 6350 & 6350 & 6350 \\
\hline
\end{tabular}




\section{Table 5. Regression results for equation (2)}

This table presents the results of regressing measures of the volatility of market equity beta on firm age and other determinants of systematic risk using fixed effects during the period from 1993 to 2014 (equation 2). Table 1 presents de definitions of the variables included in this table, the construction of the variables is discussed in the appendix. We winsorize observations in the outside $1 \%$ of each tail of the growth, businessrisk, financialleverage, operatingrisk, and growthoptions variables to mitigate the effect of extreme values in the regressions. Note that we include time dummy variables to control for the impact of contemporaneous macroeconomic conditions which affect all firms but change over time. ${ }^{* *}$ and $*$ indicate a statistically significant coefficient at the $1 \%$ and $5 \%$ level respectively. We report standard errors clustered by firm in parentheses.

\begin{tabular}{|c|c|c|c|c|c|}
\hline Variable & Predicted sign & $2 a$ & $2 \mathrm{~b}$ & $\begin{array}{c}\mathbf{2 c} \\
\text { (regressand } \\
\text { winsorized) }\end{array}$ & $\begin{array}{c}\mathbf{2 d} \\
(\mathrm{MAD})\end{array}$ \\
\hline Intercept & + & $\begin{array}{l}5.2095^{* *} \\
(1.0092)\end{array}$ & $\begin{array}{l}5.2034^{* *} \\
(1.0019)\end{array}$ & $\begin{array}{l}3.6142 * * \\
(0.4262)\end{array}$ & $\begin{array}{c}3.6870 * * \\
(0.7193)\end{array}$ \\
\hline firmage & - & $\begin{array}{l}-0.0336^{* *} \\
(0.0119)\end{array}$ & $\begin{array}{l}-0.0330 * * \\
(0.0087)\end{array}$ & $\begin{array}{l}-0.0191 * * \\
(0.0034)\end{array}$ & $\begin{array}{l}-0.0239 * * \\
(0.0062)\end{array}$ \\
\hline firmage ${ }^{2}$ & + & $\begin{array}{c}0.0000 \\
(0.0001)\end{array}$ & & & \\
\hline growth & + & $\begin{array}{c}0.1300^{*} \\
(0.0613)\end{array}$ & $\begin{array}{c}0.1303 * \\
(0.0622)\end{array}$ & $\begin{array}{l}0.0802 * * \\
(0.0279)\end{array}$ & $\begin{array}{c}0.0900 * \\
(0.0438)\end{array}$ \\
\hline businessrisk & + & $\begin{array}{c}0.0825 \\
(0.0834)\end{array}$ & $\begin{array}{c}0.0827 \\
(0.0825)\end{array}$ & $\begin{array}{c}0.1040 \\
(0.0662)\end{array}$ & $\begin{array}{c}0.0648 \\
(0.0612)\end{array}$ \\
\hline financialleverage & + & $\begin{array}{c}0.3281 \\
(0.2320)\end{array}$ & $\begin{array}{c}0.3282 \\
(0.2322)\end{array}$ & $\begin{array}{c}0.2450^{*} \\
(0.1143)\end{array}$ & $\begin{array}{c}0.2373 \\
(0.1652)\end{array}$ \\
\hline operatingrisk & + & $\begin{array}{c}0.0001 \\
(0.0060)\end{array}$ & $\begin{array}{c}0.0001 \\
(0.0060)\end{array}$ & $\begin{array}{c}0.0030 \\
(0.0033)\end{array}$ & $\begin{array}{c}0.0004 \\
(0.0046)\end{array}$ \\
\hline firmsize & - & $\begin{array}{l}-0.2305^{* *} \\
(0.0626)\end{array}$ & $\begin{array}{l}-0.2308^{* *} \\
(0.0625)\end{array}$ & $\begin{array}{l}-0.1693 * * \\
(0.0311)\end{array}$ & $\begin{array}{l}-0.1619^{* *} \\
(0.0452)\end{array}$ \\
\hline growthoptions & + & $\begin{array}{l}-0.0196 \\
(0.0328)\end{array}$ & $\begin{array}{l}-0.0196 \\
(0.0329)\end{array}$ & $\begin{array}{l}-0.0207 \\
(0.0167)\end{array}$ & $\begin{array}{l}-0.0132 \\
(0.0236)\end{array}$ \\
\hline $\begin{array}{l}\text { Time dummy } \\
\text { variables? }\end{array}$ & & yes & yes & yes & yes \\
\hline Adjusted $\mathrm{R}^{2}$ & & 0.2897 & 0.2897 & 0.3692 & 0.2893 \\
\hline $\begin{array}{l}\text { Number of } \\
\text { observations }\end{array}$ & & 18662 & 18662 & 18662 & 18662 \\
\hline
\end{tabular}




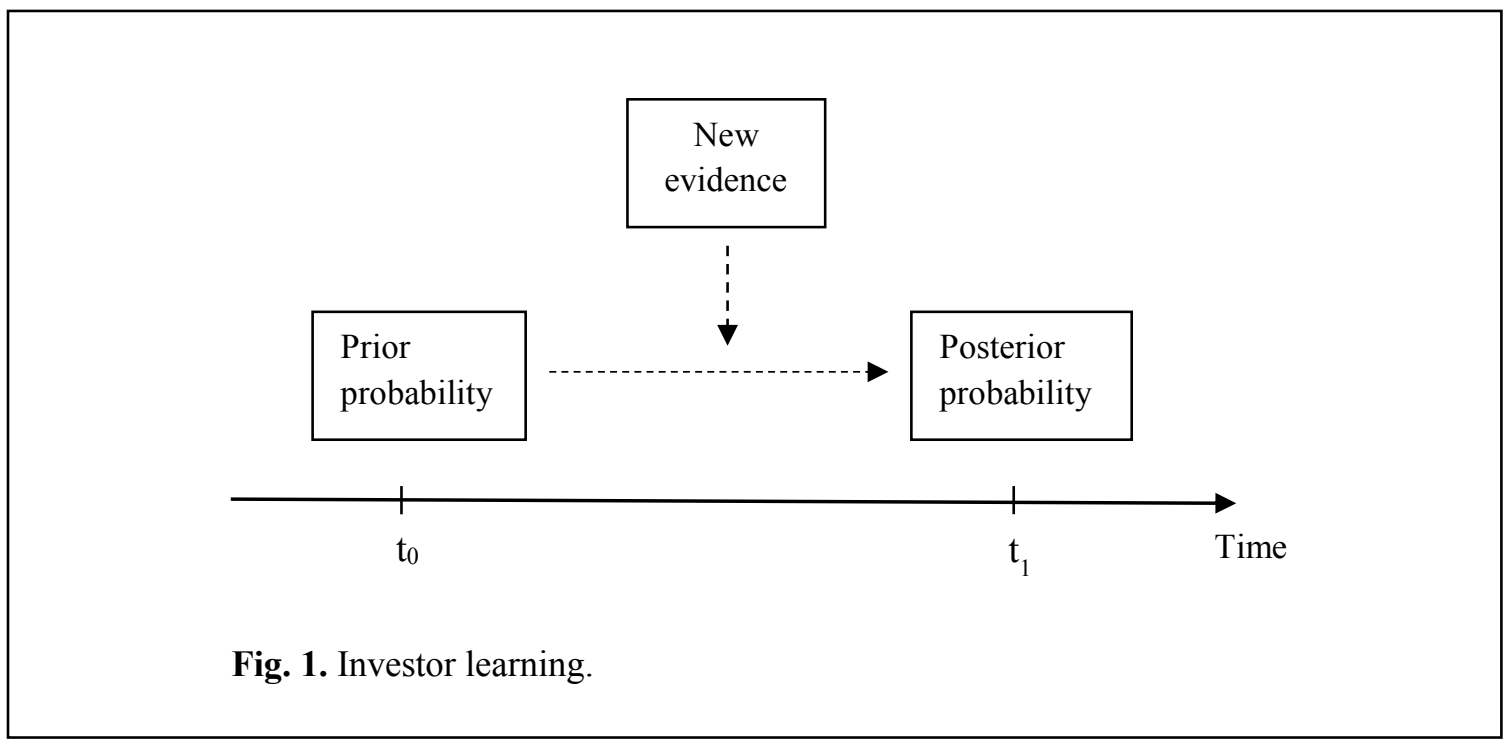




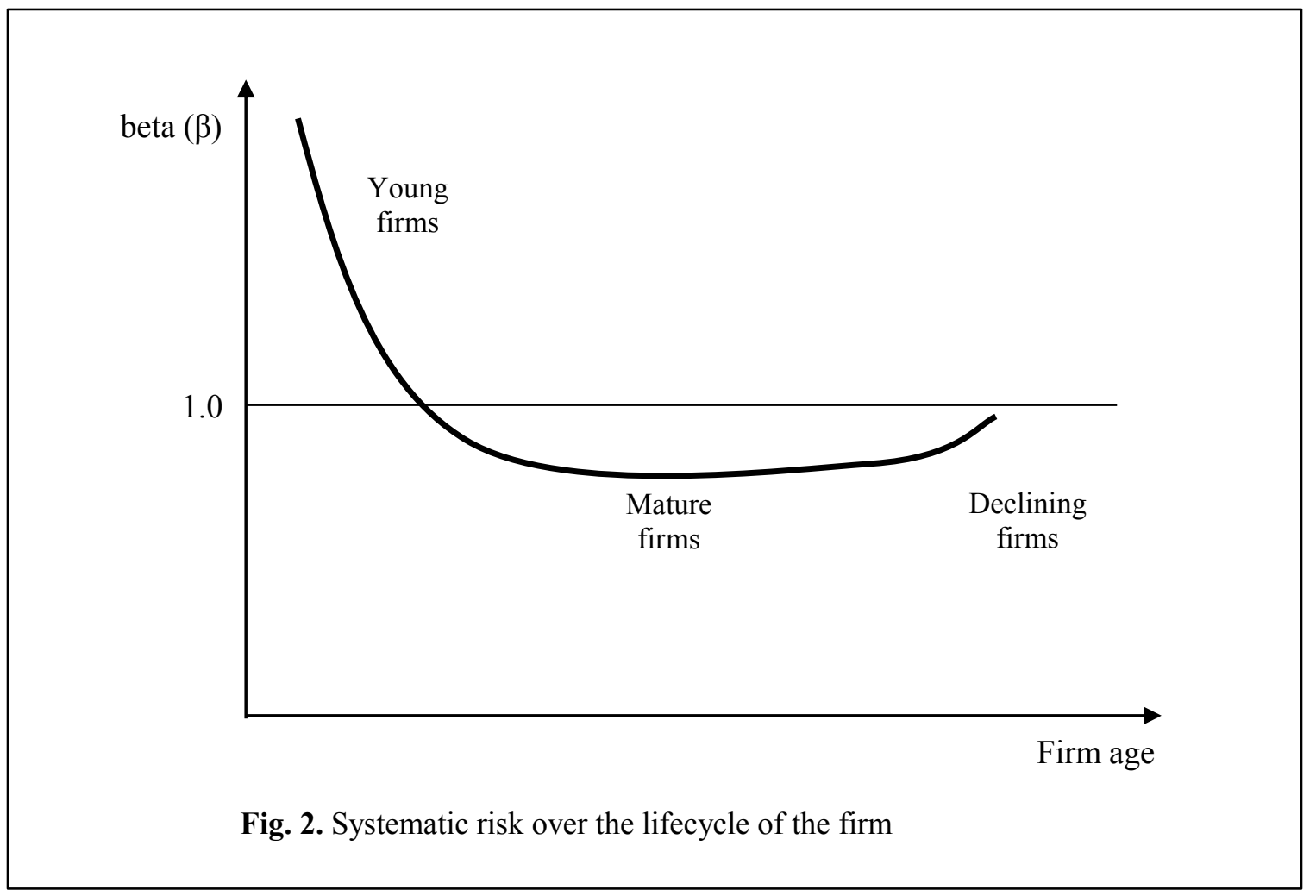

